International Journal of Agriculture, Environment and Bioresearch

Vol. 4, No. 03; 2019

ISSN: $2456-8643$

\title{
PESTICIDES RESIDUES IN SHALLOW GROUND WATERS FROM FIVE COTTON GROWING AREAS OF MALI
}

\author{
Boubacar Madio dit Aladiogo MAIGA ${ }^{1^{*}}$, Amadou MAIGA ${ }^{2}$, Ibrahima KONE ${ }^{3}$, Kalifa TOURE ${ }^{4}$, Fatoumata \\ YARO $^{5}$, Adama TOLOFOUDYE ${ }^{2}$ \\ ${ }^{1}$ Central Veterinary Laboratory, Km8 Sotuba Route de Koulikoro, BP 2295, Bamako - Mali \\ ${ }^{2}$ University of Sciences, Technics and Technologies of Bamako, PO. Box: 3206, Bamako - Mali \\ ${ }^{3}$ Professional Training Institute, BP: 53, Konobougou - Mali \\ ${ }^{4}$ National Agency of Food Security, Rue 305 BPE: 2362, Bamako-Mali \\ ${ }^{5}$ National Water Laboratory, Sotuba près du Credos PO. Box: E416, Bamako - Mali
}

http://doi.org/10.35410/IJAEB.2019.350359

\begin{abstract}
The cotton production in Mali is made with a massive use of fertilizers and pesticides. This use of pesticides against cotton pests raises questions about the level of pollution of the environment in general and the groundwater from the cotton basin of Mali in particular. The study consists of sampling shallow ground water from two areas, each considered vulnerable to ground water contamination from agricultural chemicals. It carried out in the regions of Koulikoro and Sikasso, then consisted of a search for residues of four organochlorine pesticides (DDT, dieldrin, endosulfan $\alpha$ and lindane) and one pyrethrinoid (deltamethrin) in the well water. Five sampling sites (Kassela, Koumantou, Ouelessebougou, Sido and Tienfala) were explored. Two collection seasons were carried out in September 2016 (S1) and September 2017 (S2). They involved a total of 104 well water samples divided into 78 wells without margins and 26 wells with margins. The samples were extracted and analyzed by a gas chromatograph equipped with an Electron Capture Detector. The results show the presence of pesticide residues at measurable concentration for 80 of the 104 wells from the five sites. Pesticides residues were determined in $76.92 \%$ of the samples. The pesticide with the highest detection frequency was Deltamethrin which was detected in 20 of the 80 contaminated wells.
\end{abstract}

Keywords: Cotton production, Pesticides, Well water, Pollution and Mali.

\section{INTRODUCTION}

Mali is a Sahelian country with agriculture as the engine of its economy. It contributes $35 \%$ to the formation of the gross domestic product (GDP) and is the main source of incomes for the majority of the rural population (INSTAT, 2013). However, this agriculture depends on the vagaries of the weather, particularly rainfall and the attacks of many pests, diseases, weeds and sometimes the occurrence of avian or locust infestations. Under the combined effects of disease, pest attack and weed competition, it is estimated that more than $50 \%$ of global agricultural production is lost before or after harvest (FAO, 2002). This finding justifies the use of pesticides 
in order to guarantee agricultural production and secure the storage of products. The fight against pests has led to an increase in the use of pesticides in agricultural production. This use, which is often unsecured, can seriously endanger both health and the environment.

Mali in its quest for alternatives to poverty and dependence on food imports is increasingly engaged in intensifying cotton and rice cultivation through hydro-agricultural schemes coupled with increasing use of fertilizers and pesticides. Cotton is a product of a cash crop, playing a leading role in the national economy while rice is an important part of people's diet. The objectives of agricultural production on the same lands are inscribed in a continual logic of increase. The satisfaction of this ambition requires both an increase in volume and a diversification of chemicals molecules. Each of these two factors may be a potential source of environmental pollution by pesticide residues.

The total amount of pesticides applied to agricultural land varies according to the type of crop, the pests present, the climatic conditions and the producing agricultural regions (Tellier, 2006). They may present, in addition to their intended effects on the pests or organisms concerned, very variable hazards for humans and ecosystems, with immediate or long-term impact (IFEN, 2007). The conditions of their use and characteristics of the environment, are at the origin of the fact that they can be found in several compartments of the environment as well as in the foodstuffs. Particularly exposed areas are: cultivated and surrounding areas (which may be home to wildlife), wells, creeks and streams (Cox, 2002).

Most communities living in the agricultural areas of South-Mali, usually consume shallow groundwater from farm wells. Drinking water from wells located near cotton fields is exposed to pollution by pesticides. In these conditions, drinking water is increasingly polluted and poses a threat to public health (Ngom et al., 2012, Akpo et al., 2016). In recent decades a large cotton production activity has been developed in the region that could lead to a degradation of the water resources of the water table. Previous studies (Dem et al., (2007) and Maïga et al., (2014)) had shown the presence of pesticide residues in well water located in the cotton production area. The use of agricultural chemicals in cotton production is widespread in Mali, however, the effects of these chemicals on the agricultural areas' ground water are largely unknown. The objective of this study is to provide information on the presence and concentration of pesticide residues in ground water resulting from pesticide usage in cotton production sites. It is an initial step toward defining these effects.

\section{MATERIALS AND METHODS}

\subsection{Study area and period}

Five sites located in the cotton producing areas in the Koulikoro and Sikasso regions were chosen on the basis of the intensity of cotton production, the existence of wells located near the cotton fields whose waters are used as drinking water by the populations (Figure 1). The sites were chosen by targeting two distinct zones: zone 1 of large cotton production made up of 3 sites (Koumantou, Ouelessebougou and Sido) and zone 2 of low cotton production with 2 sites (Tienfala and Kassela).

The samples were collected during two seasons (Season 1 (S1): September 2016 and Season 2 (S2): September 2017). 


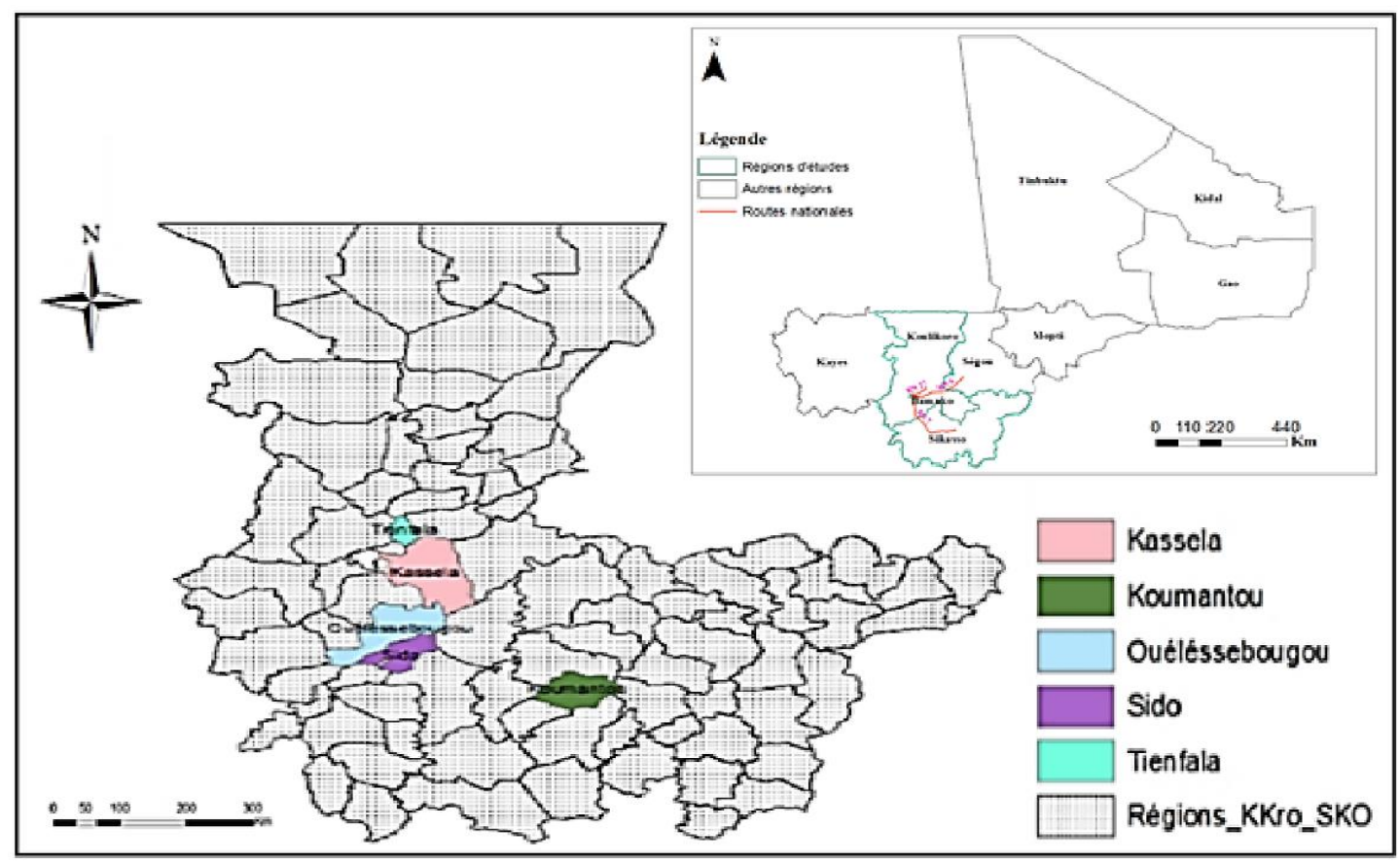

Figure 1: Map and sites of the study area in Mali

\subsection{Selection of wells and sampling}

The wells targeted in this study are located near the cotton fields, with a depth of between 5 and 18 meters depending on the geomorphology of the sites and their water is used for human consumption. 104 well water samples with a total volume of $1000 \mathrm{~mL}$ each were collected in glass bottles and labeled with an indelible ink code. They consist of 78 well water samples without rim and 26 well water samples with curb. The samples were immediately placed under refrigeration plates at a temperature between $+4^{\circ}$ and $+8^{\circ} \mathrm{C}$ and transported as quickly as possible to the laboratory. Samples were received by the laboratory within 72 hours of collection.

Table 1: Number of samples taken per site

\begin{tabular}{|lcccccc|}
\hline \multirow{2}{*}{ Sample of Water } & \multicolumn{5}{c|}{ Site } & \\
\cline { 2 - 6 } & Kassela & Koumantou & Ouelessebougou & Sido & $\begin{array}{c}\text { Tienfal } \\
\text { a }\end{array}$ & \\
\hline $\begin{array}{l}\text { Well without } \\
\text { margins }\end{array}$ & 15 & 20 & 18 & 16 & 09 & $\mathbf{7 8}$ \\
Well with margins & 04 & 06 & 05 & 06 & 05 & $\mathbf{2 6}$ \\
Total & $\mathbf{1 9}$ & $\mathbf{2 6}$ & $\mathbf{2 3}$ & $\mathbf{2 2}$ & $\mathbf{1 4}$ & $\mathbf{1 0 4}$ \\
\hline
\end{tabular}

\subsection{Samples processing and analysis}

The samples were processed and analyzed according to an internal method of the Central Veterinary Laboratory of Bamako for the determination of pesticides residues in water samples, validated according to ISO 10382-AFNOR 31.X.C: 2003.

\subsubsection{Extraction, concentration and purification}


For extraction, a sample of $500 \mathrm{~mL}$ of water was taken, transferred to a separating funnel and mixed with $50 \mathrm{~mL}$ of hexane and $10 \mathrm{~mL}$ of saturated sodium chloride $(\mathrm{NaCl})$. This mixture is stirred vigorously for 10 minutes while allowing the gas to be released periodically and then allowed to settle for 5 minutes. Then the aqueous phase is recovered in a $500 \mathrm{~mL}$ Erlenmeyer flask and the organic phase in a $250 \mathrm{~mL}$ flask. This phase is repeated 3 times in succession without the $\mathrm{NaCl}$. The organic phases obtained were combined in the separating funnel and the hexane extract is filtered in the presence of sodium sulphate $\left(\mathrm{Na}_{2} \mathrm{SO}_{4}\right)$ and glass wool. The filtrate is collected in a $500 \mathrm{~mL}$ flask and preconcentrated at $35^{\circ} \mathrm{C}$ on a rotary evaporator to about $2 \mathrm{~mL}$. It is placed in a graduated test tube, then the flask is rinsed with $8 \mathrm{~mL}$ of hexane to make up to $10 \mathrm{~mL}$ for purification. The purification cartridges are rinsed with $5 \mathrm{~mL}$ of a mixture S2 (hexane-diethyl ether 60/40) and $5 \mathrm{~mL}$ of hexane. $1 \mathrm{~mL}$ of the extract is passed through these cartridges, which are left to taste retaining the supernatant. $5 \mathrm{~mL}$ of the solution $\mathrm{S} 1$ (hexanediethyl-ether 80/20) are added to $5 \mathrm{~mL}$ of the solution $\mathrm{S} 2$. This final volume is conditioned in hexane and transferred to a $10 \mathrm{~mL}$ vial. Finally, a $1.5 \mathrm{~mL}$ sample of the final volume is taken and transferred to a vial for gas chromatograph (GC) analysis.

\subsubsection{Solutions of analytical standards}

The analytical reference standards of the five pesticides of purity between 96.3 and $98.5 \%$ were acquired from the manufacturer (Ehrenstorfer $\mathrm{GmbH}$ Reference Augsburg-Germany). An individual solution of each standard required for identification and quantification was prepared by diluting the stock solution in hexane "for residues". The solution of the mixture of five concentration standards $5 \mu \mathrm{g} / \mathrm{mL}$ was prepared by dilution in hexane. Then an assay range of five different levels at concentrations $(0.0125,0.25,0.5,0.1$ and $0.125 \mu \mathrm{g} / \mathrm{mL})$ was prepared and used for GC calibration.

\subsubsection{Instrumental analysis}

Sample extracts were analyzed by gas chromatograph (Agilent 7890A) with an electron capture detector (ECD) and CHEMSTATION operating software. A capillary column Crossbond RTX5, 30 meters $\times 250 \mu \mathrm{m}$ internal diameter x $0.50 \mu \mathrm{m}$ film thickness, stationary phase $5 \%$ diphenyl95\% dimethyl polysiloxane was used. An HP-5 column (5\% Phenyl methyl siloxane) confirmed the status of the samples already analyzed (negative and positive). The injector was in splitless mode at a temperature of $280^{\circ} \mathrm{C}$ with nitrogen as a carrier and make-up gas of $60 \mathrm{~mL} / \mathrm{min}$ and a constant flow rate of $1.6 \mathrm{~mL} / \mathrm{min}$. The programming of the furnace temperature in three stages was as follows: an initial plateau between $70-150^{\circ} \mathrm{C}$ followed by a secondary plateau of $150-$ $200^{\circ} \mathrm{C}$ and a last one of $200-280^{\circ} \mathrm{C}$. The detector was programmed at a temperature of $300^{\circ} \mathrm{C}$ for a volume of the injected sample of $1 \mu \mathrm{L}$.

\subsubsection{Recovery rate}

Known quantities of standard solution of the five desired pesticides were individually added to previously verified water samples that did not contain pesticide residues. The amount recovered was expressed as a percentage of the amount added. For five passages of each doped pesticide, the recovery rates were of the order of $93 \%$ for DDT and Deltamethrin, $92 \%$ for Dieldrin, $91 \%$ Endosulfan $\alpha$ and $90 \%$ for Lindane.

\subsubsection{Statistical data processing}


The Win Episcope version 2.0 software allowed to set the sample size for an estimated prevalence of $7.8 \%$, with a $95 \%$ confidence level and a margin of error of $5 \%$. After the analytical phase, the raw results were captured and processed for variance analysis (ANOVA) using the 2nd edition of 2010 SAS version 9.2 software.

\section{RESULTS}

The situation of the samples after the analysis is presented in Table 2, the number of positive samples per site, per pesticide encountered during collection season is presented in Table 3 .

Table 2: Situation of well water samples after analysis

\begin{tabular}{|c|c|c|c|c|}
\hline \multirow{2}{*}{ Collection season } & \multicolumn{2}{|c|}{ Pesticides Residues } & \multirow{2}{*}{ Total } & \multirow{2}{*}{$p$-value } \\
\hline & Present & Absent & & \\
\hline September 2016 (S1) & 37 & 15 & 52 & \\
\hline September 2017 (S2) & 43 & 09 & 52 & 0.1626 \\
\hline Total & 80 & 24 & 104 & \\
\hline
\end{tabular}

The results obtained indicate the quantification of pesticide residues in 80 well water samples out of 104 in the study area, with a contamination rate estimated approximately to $76.92 \%$, of which 37 in September 2016 compared to 43 samples in September 2017.

Table 3: Number of Samples with Pesticide Residues by Site and by Collection Season

\begin{tabular}{|c|c|c|c|c|c|c|c|c|c|c|c|c|c|c|c|c|}
\hline \multirow{2}{*}{ Sites } & \multicolumn{3}{|c|}{$\begin{array}{c}\text { Number of } \\
\text { samples taken }\end{array}$} & \multicolumn{2}{|c|}{ DDT } & \multicolumn{2}{|c|}{$\begin{array}{c}\text { Dieldr } \\
\text { in }\end{array}$} & \multicolumn{2}{|c|}{$\begin{array}{c}\text { Deltamet } \\
\text { hrin }\end{array}$} & \multicolumn{4}{|c|}{$\begin{array}{cc}\text { Endosulfa } & \text { Linda } \\
\text { n } \alpha & \text { ne }\end{array}$} & \multicolumn{3}{|c|}{ Total par site } \\
\hline & S1 & S2 & $\begin{array}{c}\text { Plurali } \\
\text { ty }\end{array}$ & S1 & S2 & S1 & S2 & S1 & S2 & S1 & S2 & S1 & S2 & S1 & $\mathbf{S 2}$ & $\begin{array}{c}\text { Plurali } \\
\text { ty }\end{array}$ \\
\hline $\begin{array}{l}\text { Ouelesseb } \\
\text { ougou }\end{array}$ & 11 & 12 & 23 & 2 & 2 & 1 & 2 & 3 & 3 & 2 & 2 & 2 & 2 & 10 & 11 & 21 \\
\hline $\begin{array}{l}\text { Koumant } \\
\text { ou }\end{array}$ & 13 & 13 & 6 & 3 & 2 & 3 & 2 & 2 & 2 & 2 & 2 & 1 & 3 & 11 & 11 & 22 \\
\hline Sido & 11 & 11 & 22 & 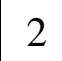 & 2 & 1 & 2 & 3 & 3 & 1 & 2 & 2 & 1 & 8 & 12 & 2 \\
\hline Kassela & 10 & 09 & 19 & 1 & 2 & 1 & 1 & 2 & 2 & 1 & 1 & 1 & 1 & 6 & 7 & 13 \\
\hline Tienfala & 07 & 07 & 14 & 1 & 1 & 0 & 0 & 0 & 0 & 1 & 1 & 0 & 0 & 2 & 2 & 4 \\
\hline Total & 52 & 52 & 104 & 9 & 9 & 6 & 7 & 10 & 10 & 7 & 8 & 6 & 7 & 37 & 43 & 80 \\
\hline
\end{tabular}
S1 : September 2016 S2 : September 2017

The results of the pesticides analyzes indicated, that these shallow groundwater wells contain pesticide residues. This contamination varies according to agricultural production activities of the site. The observation in Table 3 shows that the numbers of samples containing DDT and Deltamethrin were identical for both sampling seasons. The Koumantou and Tienfala sites also had the same number of contaminated samples for both seasons, while the Ouelessebougou and Kassela sites had one more sample in S2 than in S1. Finally, the Sido site showed a higher 
number of samples contaminated by pesticide residues in S2. However, no significant difference was found $(\mathrm{p}=0.1626)$ depending on the sampling season (Table 2).

Table 4: Samples after Analyzes According to their Origin

\begin{tabular}{|lcccc|}
\hline \multirow{2}{*}{ Sample water from } & \multicolumn{2}{c}{ Pesticides Residues } & \multirow{2}{*}{ Total } & p-value \\
\cline { 2 - 3 } & Present & Absent & & \\
\hline Well with margins & 16 & 10 & 26 & \\
Well without margins & 64 & 14 & 78 & 0.0316 \\
Total & $\mathbf{8 0}$ & $\mathbf{2 4}$ & $\mathbf{1 0 4}$ & \\
\hline
\end{tabular}

Out of twenty-six well with margins water samples analyzed, pesticide residues were found in sixteen samples with concentrations ranging from 0.2 to $12.24 \mu \mathrm{g} / \mathrm{L}$. Of the seventy-eight (78) well water samples without margins, pesticide residues were detected and quantified in 64 at concentrations ranging from 6.68 to $54 \mu \mathrm{g} / \mathrm{L}$.

A significant difference was found between the contamination of wells without margins and wells with margins through a p-value $=0.0316$ (Table 4).

The average pesticide residue concentrations expressed in $\mu \mathrm{g} / \mathrm{L}$ are summarized in Table 4 (for Season S1) and Table 5 (for Season S2).

Table 4: Mean results expressed in $\mu \mathrm{g} / \mathrm{L}$ for season $\mathrm{S1}$ (September 2016)

\begin{tabular}{|c|c|c|c|c|c|c|}
\hline Pesticides & $\begin{array}{l}\text { Ouelesseboug } \\
\text { ou }\end{array}$ & $\begin{array}{l}\text { Koumanto } \\
\text { u }\end{array}$ & Sido & $\begin{array}{l}\text { Kassel } \\
\text { a }\end{array}$ & $\begin{array}{l}\text { Tienfal } \\
\text { a }\end{array}$ & Total/Pesticide \\
\hline DDT & 16,5 & 15,5 & 15,6 & 11,2 & 09 & 67,8 \\
\hline Dieldrine & 6,5 & 8,7 & 3,8 & 1,7 & 1,5 & 22,2 \\
\hline $\begin{array}{l}\text { Deltaméthrin } \\
\text { e }\end{array}$ & 33 & 54 & 21 & 19 & 15 & 142 \\
\hline $\begin{array}{l}\text { Endosulfane } \\
\boldsymbol{\alpha}\end{array}$ & 22 & 30 & 28 & 09 & 06 & 95 \\
\hline Lindane & 0,5 & 0,3 & 0,2 & 0,2 & 0,2 & 1,4 \\
\hline Total/Site & 78,5 & 108,5 & 68,6 & 41,1 & 31,7 & 328,4 \\
\hline
\end{tabular}

Table 5: Mean results expressed in $\mu \mathrm{g} / \mathrm{L}$ for season $\mathrm{S2}$ (September 2017)

\begin{tabular}{|c|c|c|c|c|c|c|}
\hline Pesticides & $\begin{array}{l}\text { Ouelessebougo } \\
\text { u }\end{array}$ & $\begin{array}{l}\text { Koumanto } \\
\text { u }\end{array}$ & Sido & $\begin{array}{l}\text { Kassél } \\
\text { a }\end{array}$ & $\begin{array}{l}\text { Tienfal } \\
\text { a }\end{array}$ & Total/Pesticide \\
\hline DDT & 18,2 & 17,8 & 16,7 & 14,2 & 15 & 81,9 \\
\hline Dieldrine & 6,3 & 7,9 & 4,6 & 1,5 & 1,2 & 21,5 \\
\hline $\begin{array}{l}\text { Deltaméthri } \\
\text { ne }\end{array}$ & 28 & 44 & 25 & 23 & 21 & 141 \\
\hline
\end{tabular}


Vol. 4, No. 03; 2019

ISSN: $2456-8643$

\begin{tabular}{|lcccccl|}
$\begin{array}{l}\text { Endosulfan } \\
\text { e } \boldsymbol{\alpha}\end{array}$ & 23,4 & 32 & 29,3 & 16 & 13 & $\mathbf{1 1 3 , 7}$ \\
Lindane & 0,4 & 0,4 & 0,2 & 0,2 & 0,2 & $\mathbf{1 , 4}$ \\
Total/Site & $\mathbf{7 6 , 3}$ & $\mathbf{1 0 2 , 1}$ & $\mathbf{7 5 , 8}$ & $\mathbf{5 4 , 9}$ & $\mathbf{5 0 , 4}$ & $\mathbf{3 5 9 , 5}$ \\
\hline
\end{tabular}

During the initial sampling round (S1), several occurrences of pesticides were observed in 37 wells. All results were confirmed during verification sampling (S2). According to Tables 4 and 5 relating to the results of the 5 sites for the two sampling seasons ( $\mathrm{S} 1$ and $\mathrm{S} 2$ ), there is a systematic presence of the 5 pesticides sought in the well water. Of these wells, 80 showed measurable concentration of 104 that ranged from 0.2 to $54 \mu \mathrm{g} / \mathrm{L}$. Concentration during the initial sampling ranged from $0.2 \mu \mathrm{g} / \mathrm{L}$ to $54 \mu \mathrm{g} / \mathrm{L}$ with a mean of $13.14 \mu \mathrm{g} / \mathrm{L}$. Concentration during the verification sampling round ranged from $0.2 \mu \mathrm{g} / \mathrm{L}$ to $44 \mu \mathrm{g} / \mathrm{L}$ with a mean of $14.38 \mu \mathrm{g} / \mathrm{L}$.

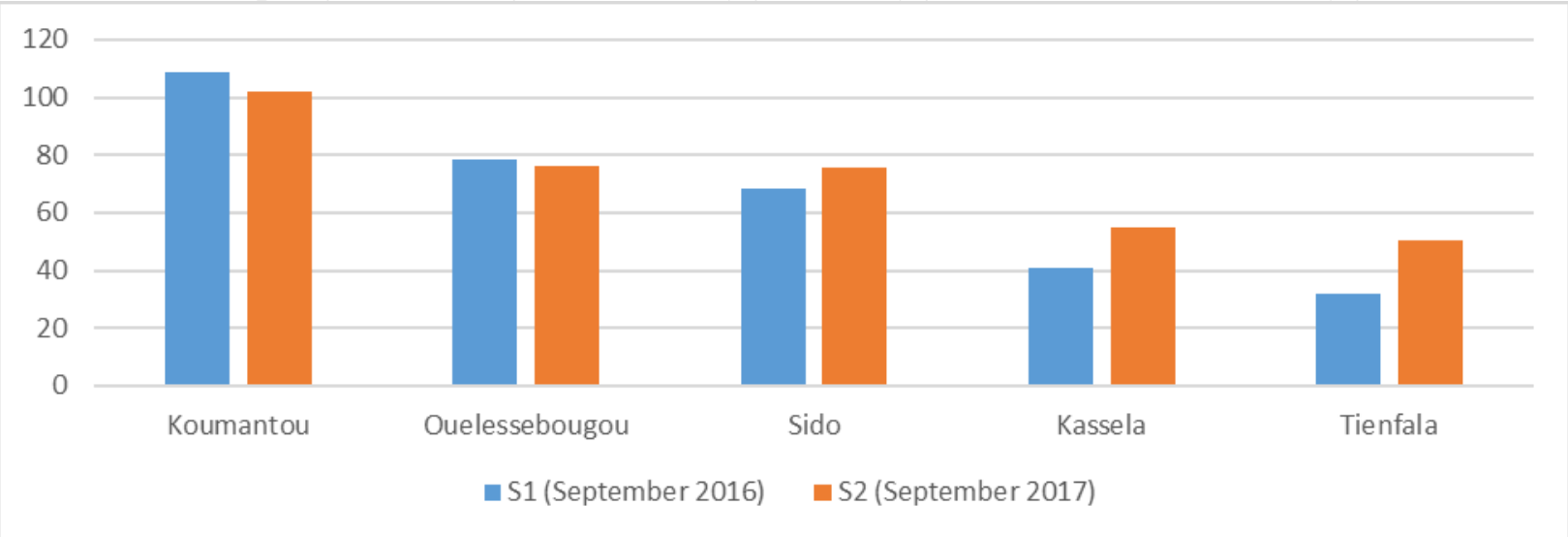

Figure 2: Cumulative rates of pesticides per site

Figure 2 shows that the three (3) sites (Koumantou, Ouelessebougou and Sido) of the zone of high cotton production (zone 1) presented more cases of contamination compared to the two (2) sites of the zone of low cotton production (zone 2). The water samples from Koumantou were the most contaminated and those from Tienfala the least contaminated.

\section{DISCUSSION}

This work consisted of characterizing groundwater quality based on local assessments of pesticide residues levels. The results obtained were compared with those obtained by other studies under similar conditions.

With regard to the contamination rate of the samples, in France for the year 2005, pesticides were present in 55\% of the groundwater monitored by the French Institute of the Environment (IFEN, 2007) while in Canada, it was estimated at 49\% for well water (Giroux, 2003), 35\% for wells located near vegetable crops and 23\% for wells in corn and soybean growing areas (Giroux et al., 2010). In Senegal, a study carried out near the edge of Tanna Lake in the Niayes gives a contamination rate of $35 \%$ of the wells (Dieng, 2008). The contamination rate of $76.92 \%$ of the samples from wells in this study area is much higher than those found in the studies cited above, lower than the rate of $88.88 \%$ of Korhogo market garden and domestic water wells in Ivory Coast (Yapo et al., 2016). The widespread contamination by pesticides can be explained by two 
facts: the two sample collections seasons take place during the months of September, which corresponds to a period rainy and crops continue to receive further treatments with pesticides. Then, the wells that were sampled are traditional wells, the majority of which are without curbs and receive the runoff water directly. Tapsoba et al., 2006 concluded that the very strong cotton activity in the village and especially in the cotton field leads to a high pollution in the wells, infiltration of pesticides into the soil and water runoff during the rainy season.

Analysis of the well water samples revealed the presence of the checked pesticides (endosulfan, deltamethrin, dieldrin, lindane, op'DDT). These four organochlorine pesticides were found in the waters of the Nakamba dam in Burkina Faso (Ouattara et al., 2012) and other authors in West Africa (Soclo, 2003; Mawussi, 2008; Agagbé, 2008; Agbohessi et al., 2012; Ngom et al., 2012). Deltamethrin has been quantified in well water in Korhogo (Yapo et al., 2016), in Niayes (Ngom et al., 2012). Already the study conducted in the cotton producing area in 2007 detected the residues of eight pesticides in well water at low volumes (Dem et al., 2007), then the work of Maiga et al., (2014) resulted in quantifications of organochlorine pesticides in well waters to finish with the results of this study which found high levels of organochlorine pesticides with deltamethrin. The autors Aikpo et al., (2015) concluded that the pesticides widespread presence in all samples at high levels presage of an uncontrolled use of these products. This presence of pesticide residues in the well waters, can be explained by recent use of Deltamethrin in market garden production near wells without coping for most of them. In the case of the four organochlorine pesticides (DDT, Dieldrin, Endosulfan and Lindane) it can be explained both by the resultant of past use because of their persistent characters but also by their current illegal use in the production of cotton.

The water samples from Koumantou (zone 1) were the most contaminated and those from Tienfala (zone 2) the least contaminated. This result is explained by the fact that cotton crops in these localities are subject to pesticide treatment. The low detection frequency of pesticides in the zone 2 study area may be a function of the intensity of cotton production at the local level. According to Maïga et al., (2014), insecticides treatments are performed in cotton fields from July to September. Frequency of treatment, interval between treatments (from one to two weeks) and application rate are set by farmer according to the degree of parasitic infestation of cotton plant during the cropping season. The level of pollution is proportional to the intensity of cotton production at the local level. The proximity of groundwater sources to cotton fields is likely to be the source of contaminations by runoff and infiltration of rainwater.

\section{CONCLUSION}

The results of the analyzes provide an overview of well water contamination in each of the two observation zones for the two sampling campaigns in this study. During the investigation, it was determined that wells in the high cotton production area were more contaminated than those in the small production area. The identified wells are contaminated with runoff and infiltration of precipitation water to wells located near the cotton fields. The levels of contamination found were often significant, that can be explain by organochlorine pesticides banned in agricultural production are still used by producers. Indicating that the use of pesticides in cotton production poses a threat to water quality and could have negative effects on the environment and public health.

\section{REFERENCES}


A. Maïga, H. Blanchoud, D. Diallo, F. Alliot, A.S. Cissé, M. Chevreuil, 2014. "Pesticide Occurrence in an Alfisol of Sudano-Sahelian Agricultural Watershed (Korokoro, Mali)," Int. Journal of Engineering Research and Applications, 4 (8), pp. 130-141.

A. A. Agagbé, 2008. Etude écotoxicochimique des résidus de pesticides dans le bassin-versant de la rivière Agbado par la technique d'analyse ELISA en phase solide. Thèse d'ingénieur des travaux en aménagement et protection de l'environnement, université d'Abomey-Calavi (Bénin).

F. H. Aïkpo, C.B. Chabi, V. Ayi, L. Koumolou, C.S. Houssou, P.A. Edorh, 2015. "Evaluation de la contamination des eaux du fleuve Couffo dans la zone cotonnière de Djidja (Bénin) par les pesticides," Int. Journal of Biological and Chemicals Sciences, 9 (3), pp. 1725-1732.

N. Dieng, L'impact du maraîchage dans la dégradation des ressources naturelles dans les Niayes de la bordure du lac Tanna. 2008

H.K. Tapsoba, Y. L. Bonzi-Coulibaly, 2006. "Production cotonnière et pollution des eaux par les pesticides au Burkina Faso," Journal Société Ouest Africaine de Chimie (21), 87-93.

H. H. Soclo, A.H. Azontondé, L. F. Dovonon, R. Djibril, A. H. Sagbo, 2003. Étude de l'impact de l'utilisation des engrais chimiques et des pesticides par les populations riveraines sur les écosystèmes (eaux de surface, substrat des réserves de faune) dans les complexes des aires protégées de la Pendjari et du W. Rapport d'étude Cotonou, Bénin : CENAGREF, p. 135.

I. Giroux, 2002. 'Contamination de l'eau par les pesticides dans les régions de culture de maïs et de soya au Québec. Résultats des campagnes d'échantillonnage 1999, 2000 et 2001, et évolution temporelle de 1992 à 2001," Ministère de l'Environnement, Gouvernement du Québec, p. 78

I. Giroux, Nadine Roy, C. Lamontagne, 2010. "Présence de pesticides dans l'eau souterraine en milieu agricole ; étude pilote du Bassin versant de la rivière Châteauguay," Canadian Water Resources Journal, 35 (4), pp. 527-542.

IFEN, 2007. Les pesticides dans les eaux. Données 2005. Les dossiers ifen, $\mathrm{N}^{\circ} 09$, document pdf, p. 39

INSTAT, 2013. Enquête Modulaire et Permanente auprès des Ménages : Profilage de la pauvreté au Mali.

J. Cox, 2002. Echantillonnage en vue de l'analyse de résidus de pesticides, in Méthodes de suivi écologique pour évaluer les effets des pesticides dans les tropiques, Ian F. Grant \& Colin C. D. Tingle (éditeurs), Chatham, R-U : Natural Ressources Institute, (6), pp. 125-147.

G. Mawussi, Bilan environnemental de l'utilisation de pesticides organochlorés dans les cultures de coton, café et cacao au Togo et recherches d'alternatives par l'évaluation du pouvoir insecticide d'extraits de plantes locales contre le scolyte du café (Hypothenemus hampei ferrari). Thèse de doctorat de l'université de Toulouse. http://ethesis.inptoulouse.fr/archive/00000935/01/mawussi.pdf, 2008. 
R. I. Yapo, V. Mambo, A. C. Alder, M. J. Ohou-Yao, R. Ligban, D. Dao, C. Stamm, B. Bonfoh, 2016. "Caractéristion saisonnière des eaux de puits à usage maraîcher et domestique de Korhogo (Côte d'Ivoire)," Int. Journal of Biological and Chemicals Sciences, 10 (3), pp. 1433-1449.

S. B. Dem, J. Cobb, D.E. Mullins, 2007. "Pesticide Residues in Soil and Water from Four Cotton Growing Areas of Mali, West Africa", Journal of Agricultural, Food and Environmental Sciences, 1 (1), pp. 1-12.

S. Ngom, S. Traore, M.B. Thiam, M. Anastasie, 2012. "Contamination des produits agricoles et de la nappe phréatique par les pesticides dans les zones des Niayes au Sénégal", Rev. Sci. Technol., Synthèse, 25, pp. 119-130.

S. Tellier, 2006. "Les pesticides en milieu agricole : état de la situation environnementale et initiatives prometteuses", Direction des politiques en milieu terrestre, Service des pesticides, Ministère du Développement durable, de l'Environnement et des Parcs, 90 p.

S. K. Akpo, L. S. Coulibaly, L. Coulibaly, I. Savane, 2016. "Temporal Evolution of the pesticides use in tropical agriculture in the Marahoué watershed, Côte d'ivoire", International Journal of Innovation and Applied Studies, 14 (1), pp. 121-131.

T.P. Agbohessi, I. I. Toko, P. Kestemont, 2012. "Etat des lieux de la contamination des écosystèmes aquatiques par les pesticides organochlorés dans le Bassin cotonnier béninois," Cahiers Agricultures, 21 (1), pp. 46-56.

Y. Ouattara, I. Guiguemde, F. Diendere, J. Diarra, A. Bary, 2012. "pollution dans le bassin du nakamba : cas du barrage de Ziga," Int. Journal of Biological and Chemicals Sciences, 6 (6), pp. 8034-8050, 